stíž, že sa ich obsah zdigitalizuje a bude verejne prístupný. Často sú to totiž diela, ktoré vyšli v nízkych nákladoch a sú už dnes nedostatkové.

EODOPEN (eBooks-On-Demand-Network Opening Publications for European Netizens) je štvorročný projekt, ktorý je spolufinancovaný Európskou komisiou v rámci programu Kreatívna Európa a podprogramu Kultúra. Ciel'om projektu je priame zapojenie občanov do procesu výberu kníh na digitalizáciu, a to na národnej, regionálnej a komunitnej úrovni. Na digitalizáciu sa budú vyberat' dokumenty z 20. a 21. storočia. Partnermi projektu sú inštitúcie z Rakúska, Estónska, Česka, Pol'ska, Slovenska, Nemecka, Portugalska, Mad'arska, Švédska, Slovinska a Litvy. Celkový rozpočet projektu je približne 4 milióny eur.
EODOPEN - sprístupňujeme knihy a periodiká občanom [online]. CVTI SR, (C2021 [cit. 25.10.2021]. Dostupné z: https://www.cvtisr.sk/buxus/docs/2021/EODOPEN web.pdf

Virtuálna študovňa Eodopen [online]. CVTI SR, C2021 [cit. 25.10.2021]. Dostupné z: https://digitalnakniznica.cvtisr.sk/ page/eod-digitalna-kniznica

Digitálne knižnice, vlastné zariadenia, dostupné formáty. CVTI SR bolo súčastou európskeho prieskumu o využívaní e-kníh [online]. CVTI SR, (C2021. Posledná zmena 10.08.2021 9:24 [cit. 25.10.2021]. Dostupné z: https://www.cvtisr.sk/aktuality-pre-odbornu-verejnost/digitalne-kniznice-vlastne-zariadenia-dostupne-formaty-cvti-sr-bolo-sucastou-europskeho-prieskumu-o-vyuzivani-e-knih.html?page id=40353

Books2ebooks [online]. EOD eBooks, C2021 [Cit. 25.10.2021]. Dostupné z: https://books2ebooks.eu/sk
Zoznam literatúry

Eodopen - Homepage [online]. EODOPEN: eBooks-On-DemandNetwork Opening Publications for European Netizens, (C2011 [Cit. 25.10.2021]. Dostupné z: http://eodopen.eu/

EODOPEN [online]. CVTI SR, C2021. Posledná zmena 10.06.2021 12:11 [cit. 25.10.2021]. Dostupné z: https://www.cvtisr.sk/eodopen
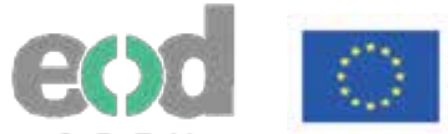

Spolufinancované $z$ programu Európskej únie Kreativna Európa

\title{
ONE RIGHTS CLEARANCE DOCUMENTATION TOOL TO ALL
}

Szabolcs Dancs; dancs.szabolcs@oszk.hu; (National Széchényi Library), Rita Radó; rado.rita@oszk.hu; (National Széchényi Library; Institute of Library and Information Science, Eötvös Lorand University)

EODOPEN working group 6 (WG6) aims at designing and developing a Rights Clearance Documentation Tool (RCDT) to support librarians in managing copyrights and licencing processes. This work includes identifying and specifying requirements of the technical infrastructure for RCDT. The work group is led by National Széchényi Library of Hungary, who is one of the members of the massive cooperation in the background of the EODOPEN project which has its roots already in the 2008 established EoD program.

https://doi.org/10.52036/1335793X.2021.3-4.43-47

\section{ABOUT THE EODOPEN PROJECT}

The history of the project described in our article dates back to 2008, when the eBooks on Demand (EoD) initiative was launched. EoD entered the second phase in 2019 with the launch of the eBooks on Demand Network "EODOPEN" project, in which fifteen libraries in Europe are working to build a common database and related services, digitize books and make them widely available.

The project is currently in the definition phase. We are creating lists of requirements, specifications, and flowcharts to facilitate decision-making about the rights management tool. We conduct surveys of good practices and methods used. The end result will be an 
open source library module suite, that will be based on a simple structure, even a cloud-based service, which is available in all of the acceding countries, but of course the network can be further expanded.

Within the project organization, the tasks can be divided into four major areas. One or more working groups are responsible for the tasks of the four major areas. In our study, we describe the activities of Working Group 6 (WG6), who are involved in the active implementation of the professional content of the fourth area the project.

The dedicated task of WG 6 is to define the requirements for the technical infrastructure of the "Rights clearance documentation tool" for the legally proper documentation of legal clearance activities. In addition, its responsibilities include the implementation and testing of the rights management documentation tool itself.

One of the members of the international partnership is the National Széchényi Library (NSZK), whose main task is to design and develop a legal clarification documentation tool within its working group (WG6) that simultaneously fits the national library's own systems and takes into account the interoperability requirements of partner institutions.

WHAT HAPPENED SO FAR...

As a part of its new library platform under development,

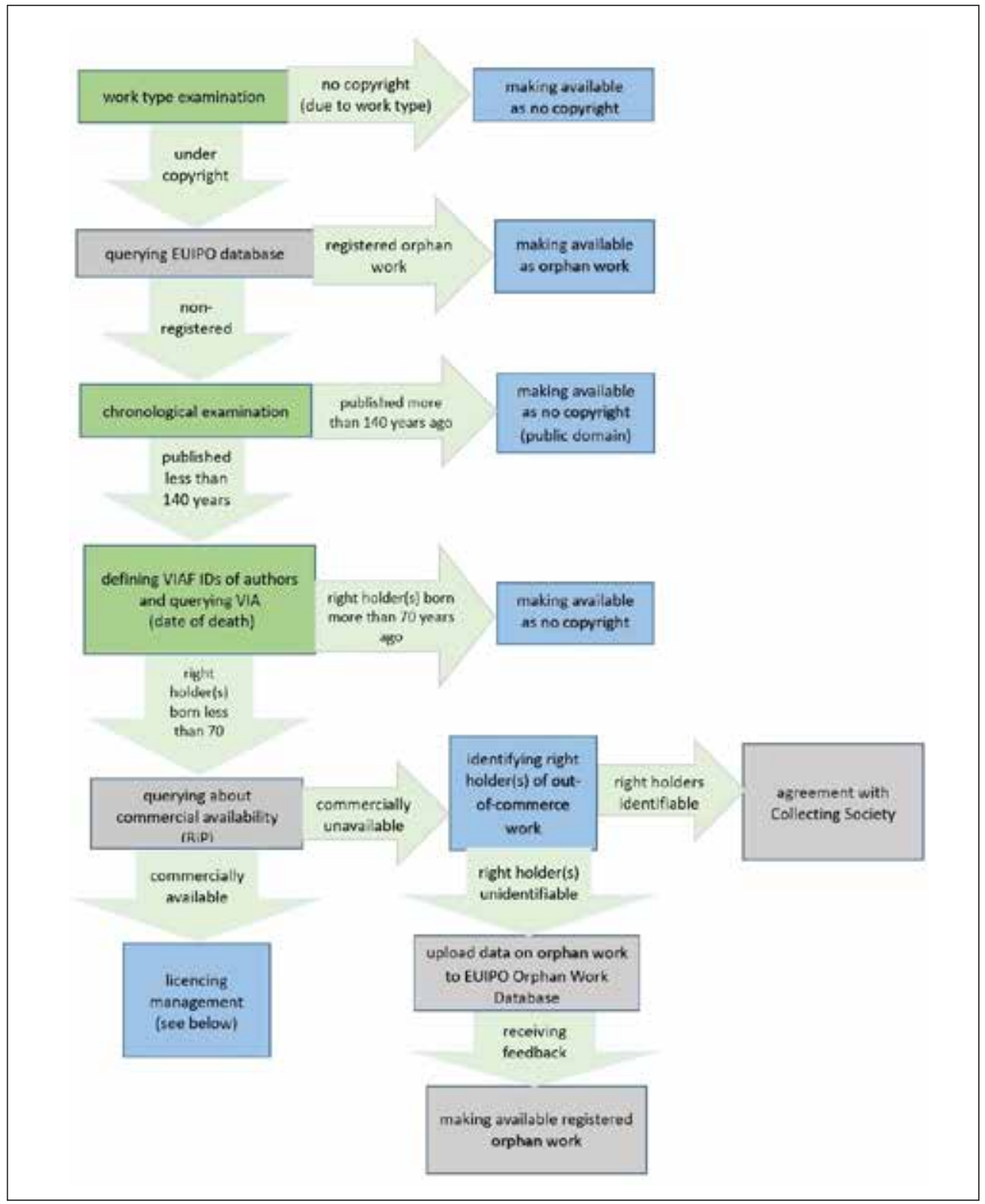

Copyright clearance workflow applied at NSL sent to partners as a guideline 
National Széchényi Library is going to implement a specific module in order to manage accesses to the contents of its digital library. It is obvious that processes of copyright clearance need to be documented in such a module. As a result of participation in EODOPEN we redesigned our system in order to make the requirements meet with those of the Rights Clearance Documentation Tool (RCDT) that is going to be developed in the framework of the project. When designing this tool the aim of Europe-wide application, therefore a quite high level of flexibility should be taken into account.

A questionnaire was sent to project partners to identify requirements. We asked them about the copyright clearance workflow applied in their institution. Workflow implemented at our library was attached to the questionnaire to serve as a guideline in responding. We also asked them about the legislative background of rights clearance and the data models considered to be implemented when developing RDT. We needed to clarify as well if the system to be designed should include licence management with its full documentation (incl. contracts and emails with right holders, etc.) and registering Creative Commons licences and Open Access declarations too.

Responses provided by our project partners have been analysed and integrated into the common workflow of copyright clearance which is an important component of the specification under construction.
Partners mainly agreed on the metadata elements and value vocabularies to use in the documentation tool. In the questionnaire we asked partners about the existence and feasibility of Books In Print databases in the relevant countries and we got to know that it is not a typical service in the region covered by project members. There is such a system in German-speaking countries (Verzeichnis Lieferbarer Bücher (VLB): www. vlb.de) which plays an important role in identifying and making available out-of-commerce works. The National and University Library in Slovenia also recognized the importance to establish and maintain a BiP service (Knjige v tisku: https://www.nuk.uni-lj.si/viri/knjige-vtisku), while in Hungary a database for managing data about availability of books is just under construction (https://opusnet.hu/). A new law forced national libraries in the Czech Republic and Slovakia to develop a sort of inverse of Books In Print databases which are for maintaining data on out-of-commerce works.

As far as providing legal access to digitized contents is concerned, existence and usability (e.g. queryability through standard interfaces) of Books in Print databases involving access data on in-commerce works became crucial as so called DSM directive came into force. The full title of the document is "Directive (EU) 2019/790 of the European Parliament and of the Council of 17 April 2019 on copyright and related rights in the Digital Single Market and amending Directives 96/9/EC and 2001/29/EC (https://eur-lex.europa.eu/legal-content/ EN/TXT/?uri=CELEX:32019L0790). Adoption of the

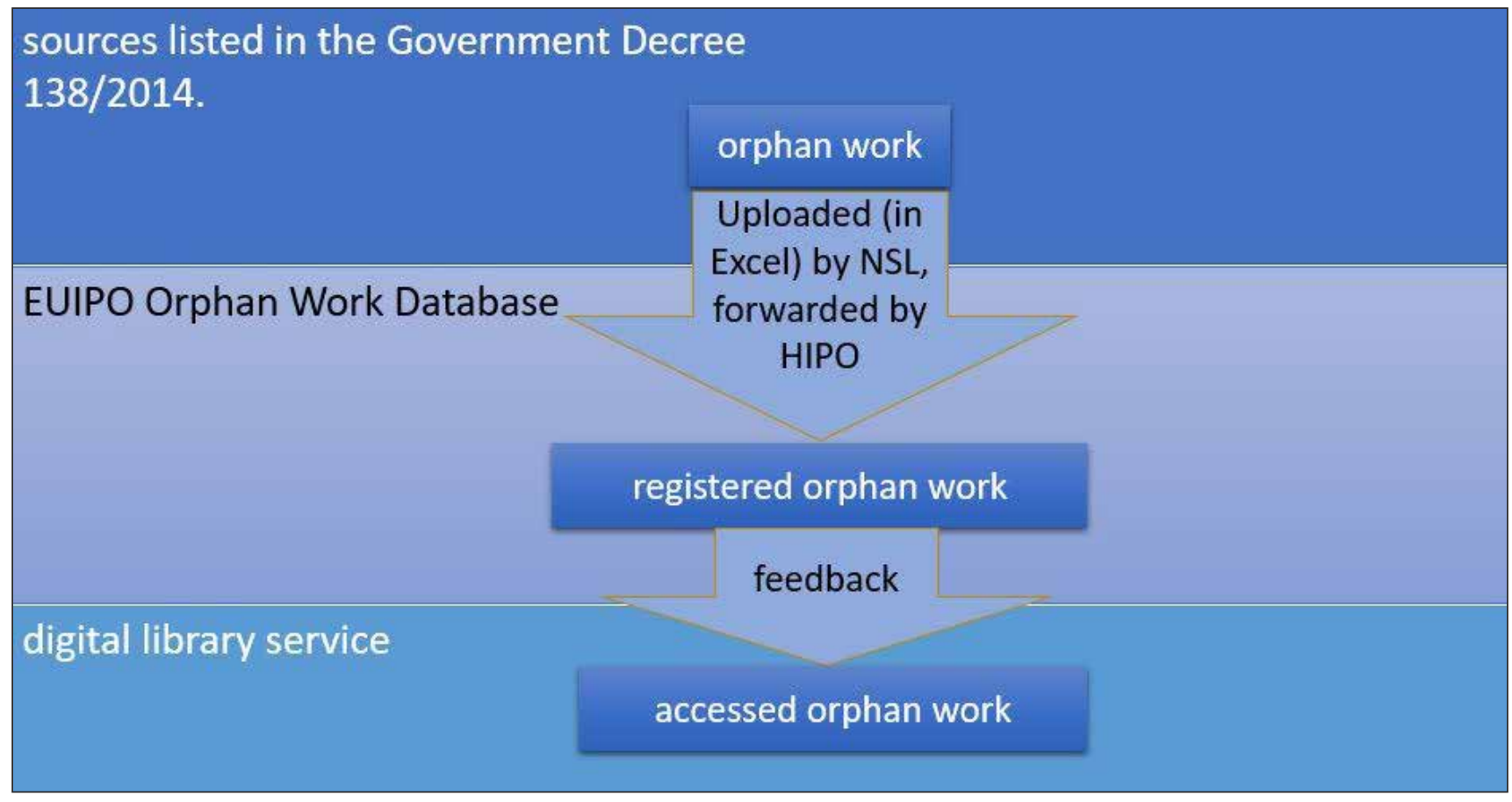


Directive by Member States might make copyright clearance procedures much simpler.

"Member States shall provide that a collective management organisation, in accordance with its mandates from rightholders, may conclude a nonexclusive licence for non-commercial purposes with a cultural heritage institution for the reproduction, distribution, communication to the public or making available to the public of out-of-commerce works or other subject matter that are permanently in the collection of the institution, irrespective of whether all rightholders covered by the licence have mandated the collective management organisation ..." (Article 8, 1.)

At the first period of the project we were not aware of what requirements the law would specify for identification of an out-of-commerce work, but it was anticipated that the requirements would be much simpler than those applied for orphan works. The original goal of EODOPEN was to support workflow for diligent search which needs to be conducted in order to identify a work as an orphan one, this goal seems to require a reconsideration.

The following illustration shows how data of works identified as orphan by diligent search is uploaded to the database maintained by European Union Intellectual Property Office (EUIPO), how this data is registered, after being forwarded by the Hungarian Intellectual Property Office (HIPO), in the database, and how orphan works become freely accessible by beneficiary institutions such as libraries.

NSL has been cooperating with EUIPO since years in the field of technical development in order to provide interoperability between their systems. In harmony with DSM Directive, data on OOC works can be accessible through a database maintained by EUIPO. According to the OOC regime, come into force in June of 2021, a work registered in EUIPO database is allowed to make digitally available six months after its registration as out-of-commerce work. In the meantime, rightholders have the possibility to exclude their works or other subject matter from the licensing mechanism set out in the Directive without any consequences, i.e. without their work being made available by $\mathrm{CHIs}$.

Systems supporting workflows outlined above need to be flexible enough in order to help stakeholders in exercising their interests in an effective way, whether they are rightholders wanting to track the distribution of their works, or content providers focusing on the credibility and promptness of copyright clearance. As a conclusion, both systems maintained by EUIPO and solutions developed in the framework of EODOPEN project need to be interoperable in the sense of the metadata schemes and interfaces for data exchange they apply.

When specifying data elements for Right Clearance

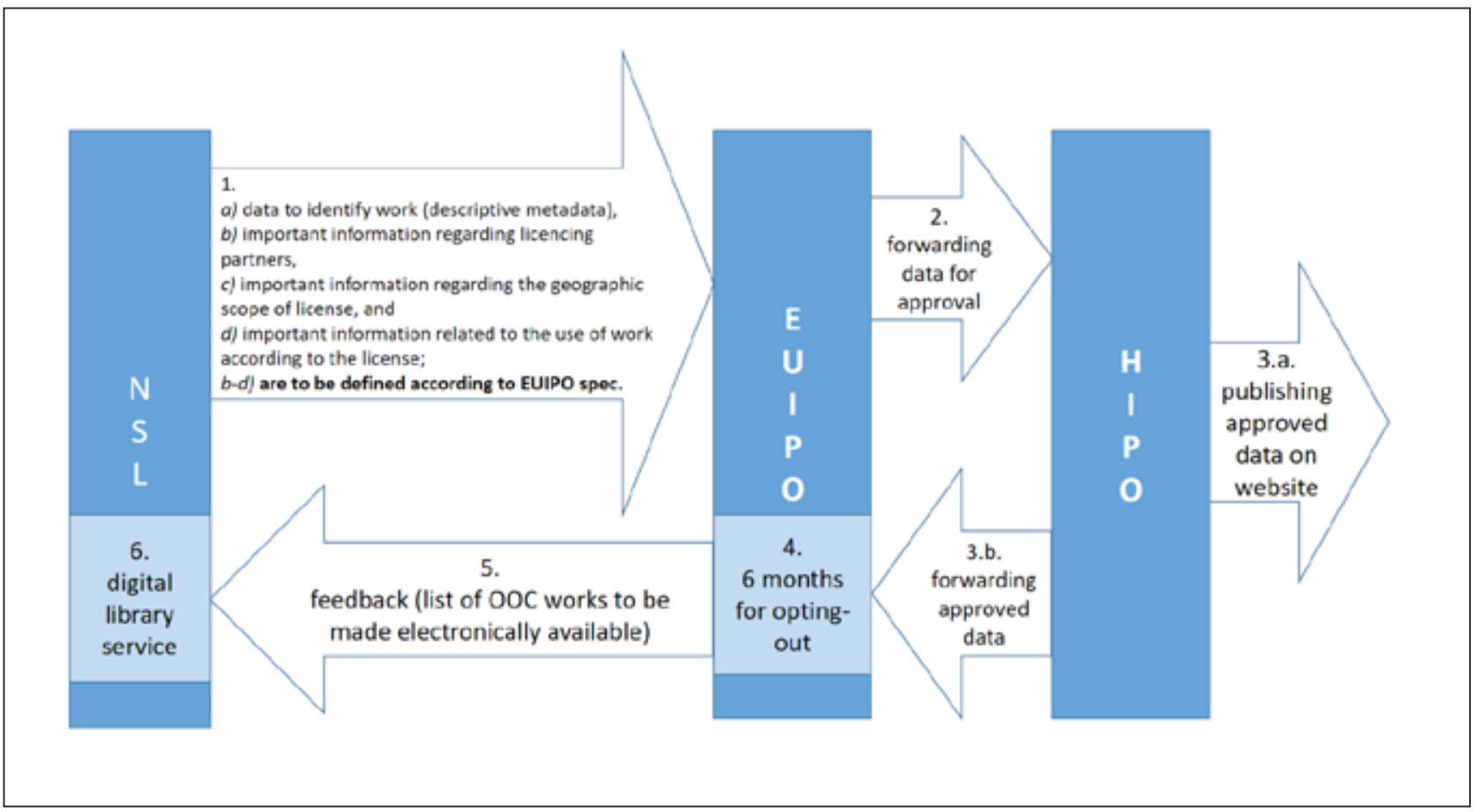

The schematic figure of workflows supporting e-library services according to the concept of technical implementation of OOC regime in Hungary. 
The conception can be realized via different schemas, the one outlined below illustrates only one of the options.

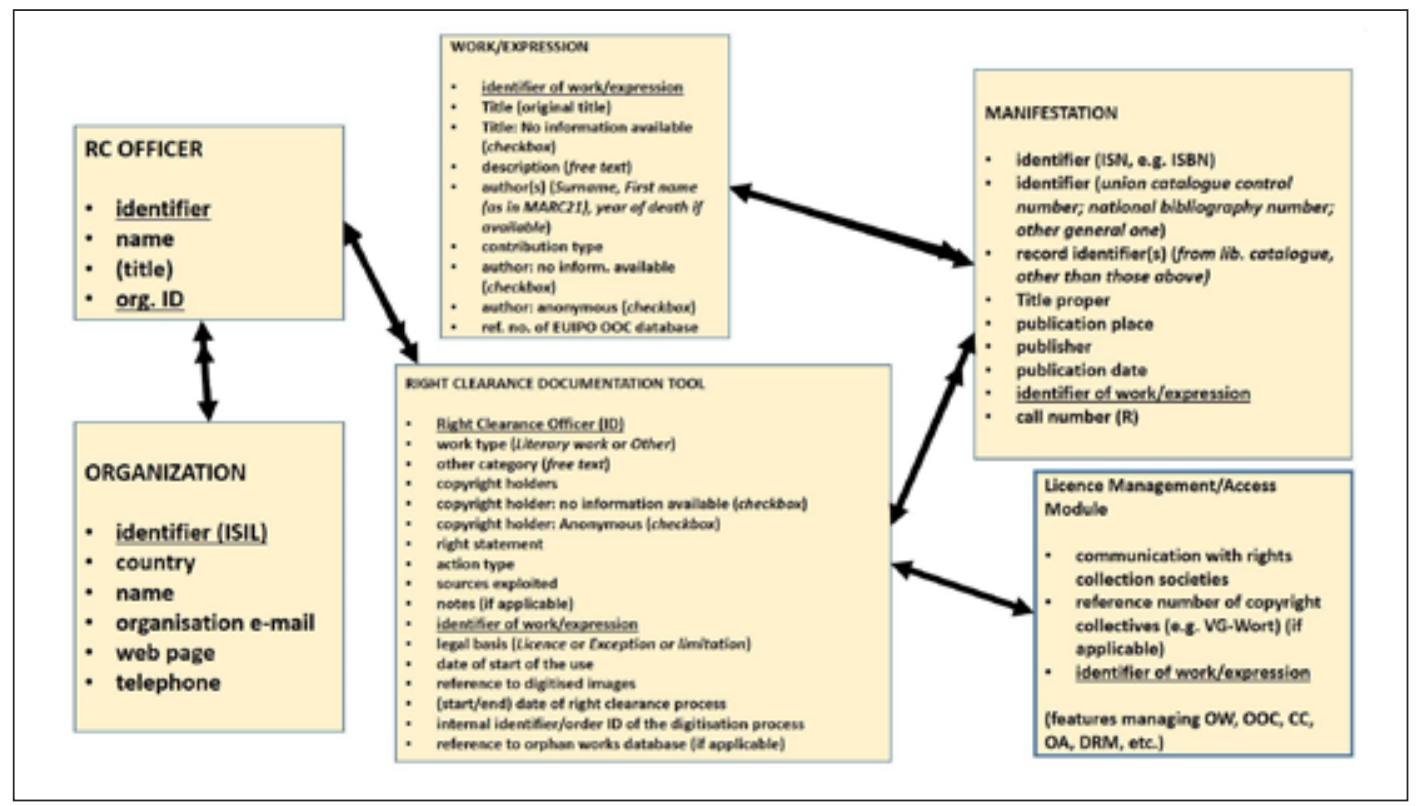

Developing a licence management system needs a deeper elaboration, including clarification of concepts by different project partners.

Licencing Management
- identifying resources published under OA licence (and indicating the fact) -
periodically searching for OA information in relevant databases (if there are) -
in Hungary: MTMT
- identifying resources published under CC licence (and indicating the fact) -
periodically searching for CC information in relevant databases (if there are) -
problematic due to the lack of sources collecting data concerned
managing licences
supporting contracting process (defining contract forms; documenting
communication with right holders; preserving signed contracts; managing
right holder data)
setting licences (DRM)
e.g. number of concurrent accesses, number of pages permitted to
print/copy, etc.
e-loan:
$\square$ in case of Public Lending Right permissions are set by libraries
$\square$ in other cases permissions are set by partner

Documentation Tool (RCDT), beyond partners' requirements compliance with EUIPO database also needs to be taken into account in order to facilitate bulk import and export of data on resources already undergone through copyright clearance. Another aspect of high importance can be the possibility of data synchronization with Books in Print databases.

\section{CONCLUSION}

As a conclusion, we might add that by the current period of the project we can clearly see the direction of developments which need to be refined according to current changes of national copyright laws (mainly due to the adoption of DSM Directive), and the situation implied by new national digitization projects. 